\title{
Anti-inflammatory and redox-protective activities of citronellal
}

\author{
Mônica S. Melo' ${ }^{1}$ Adriana G. Guimarães ${ }^{1}$, Michele F. Santana' ${ }^{1}$, Rosana S. Siqueira', \\ Amanda Do Carmo B. De Lima ${ }^{1}$, Antonio S. Dias ${ }^{1}$, Márcio Roberto V. Santos ${ }^{1}$, Alexandre S.C. Onofre ${ }^{1}$, \\ Jullyana S.S. Quintans' ${ }^{1}$, Damião P. De Sousa ${ }^{1}$, Jackson R.G.S. Almeida ${ }^{2}$, Charles S. Estevam', \\ Brancilene S. Araujo ${ }^{1}$, Lucindo J. Quintans-Júnior ${ }^{1, *}$ \\ ${ }^{1}$ Departamento de Fisiologia. Universidade Federal de Sergipe (DFS/UFS), Aracaju-SE, Brazil. \\ ${ }^{2}$ Colegiado de Ciências Farmacêuticas, Universidade Federal do Vale do São Francisco (UNIVASF), Petrolina-PE, Brazil.
}

\begin{abstract}
The anti-inflammatory and redox protective effects of the citronellal (CT) were evaluated using in vivo and in vitro tests. Intraperitoneal (i.p.) administration of CT $(50,100$, and $200 \mathrm{mg} / \mathrm{kg})$ inhibited $(\mathrm{p}<0.05)$ the carrageenan-induced leukocyte migration to the peritoneal cavity. Additionally, the carrageenan- and arachidonic acid-induced rat hind paw edema was significantly inhibited ( $p<0.05)$ by i.p. administration of 100 and $200 \mathrm{mg} / \mathrm{kg}$ of the compound. When the redox activity was evaluated, CT $(200 \mathrm{mg} / \mathrm{kg})$ significantly reduced hepatic lipoperoxidation $(\mathrm{p}<0.001)$, as well as oxidation of plasmatic $(\mathrm{p}<0.05)$ and hepatic $(\mathrm{p}<0.01)$ proteins. The results of the present study support the hypothesis that CT possesses anti-inflammatory and redox protective activities. It is suggested that its effects are associated with the inhibition of the enzymes in the arachidonic acid pathway, which prevent cell migration by inhibiting leukotriene production, edema formation and the increase of reactive oxygen species in tissues. Therefore, CT is of potential benefit to manage inflammatory disorders and correlated damages caused by oxidant agents.
\end{abstract}

Key words: Monoterpene, citronellal, anti-inflammatory, redox.

\section{INTRODUCTION}

Many plant-derived substances are attractive sources for developing new analgesic and anti-inflammatory agents. Among these natural products, monoterpenes are the primary components of plant essential oils and the effects of many medicinal herbs have been attributed to them (Gherlardini et al., 2001; De Sousa et al., 2006; De Sousa et al., 2007; Guimarães et al., 2010).

Citronellal (CT) is a monoterpene predominantly formed by the secondary metabolism of plants. It is typically isolated as a non-racemic mixture of its $R$ and $S$ enantiomers by steam distillation or solvent extraction from the oils of Corymbia citriodora Hill and Johnson (former Eucalyptus citriodora Hook) Cymbopogon nardus and C. winterianus (Lenardão et al., 2007). Preliminary behavioral screening realized with the essential oil of the $C$. winterianus, rich in $\mathrm{CT}$, demonstrated its Central Nervous System (CNS) depressant and anticonvulsant activities (Quintans-Júnior et al., 2008). Additionally, Menezes et al. (2010) showed the hypotensive and vasorelaxant effects induced by $C$. winterianus essential oil in rats. Recently, CT showed CNS depressant and antinociceptive activities on unspecific and specific tests (Melo et al., 2010; Quintans-Júnior et al., 2010). However, little is known about the role of CT in inflammatory and oxidative processes.

The purpose of the present study was to evaluate the antiinflammatory and redox effects of CT using in vivo and in vitro tests.

\section{MATERIALS AND METHODS}

\subsection{Drugs}

Polyoxyethylene-sorbitan monolated (Tween 80), carrageenan, arachidonic acid, indomethacin and nordihydroguaiaretic acid were purchased from Sigma-Aldrich (USA), while dexamethasone was obtained from Cristália (Brazil). A racemic mixture of citronellal (CT) $R$ and $S$ enantiomers [(RS)-( \pm -Citronellal] with $98 \%$ purity (Fig. 1) was purchased from Dierberger (Brazil). Agents were administrated intraperitoneally (i.p.) at a dose of $0.1 \mathrm{~mL} / 10 \mathrm{~g}$ (mice) and 0.1 $\mathrm{mL} / 100 \mathrm{~g}$ (rats). For the redox experiments, all reagents were purchased from Sigma-Aldrich (USA). INSERT FIGURE 1

\subsection{Animals}

Male Swiss mice (30-35 g) and male Wistar rats (160-190 g), 2-3 months of age, were used throughout this study. Animals were randomly housed in suitable cages at $25 \pm 2{ }^{\circ} \mathrm{C}$ on a 12 $\mathrm{h}$ light/dark cycle (lights on 06:00-18:00 h) with free access to food (Purina ${ }^{\circledR}$ ) and water, and were used in groups of 10 animals each. All experiments were carried out between 09:00 am and 16:00 pm in a quiet room. Experimental protocols and procedures were approved by the Animal Care and Use Committee at the Federal University of Sergipe (CEPA/UFS \# $12 / 08)$.

\footnotetext{
* Corresponding author: Lucindo J. Quintans-Júnior. Departamento de Fisiologia, Universidade Federal de Sergipe-UFS, Av. Marechal Rondom, s/n, São Cristóvão, Sergipe, Brazil. Tel.: +55-79-21056645; fax: +55-79-3212-6640. E-mail: lucindo_jr@yahoo.com.br; lucindo@pq.cnpq.br
} 


\subsection{Leukocyte migration to the peritoneal cavity}

Leukocyte migration was induced by injection of carrageenan (500 $\mu \mathrm{g} /$ cavity, i.p., $500 \mu \mathrm{L}$ ) into the peritoneal cavity of mice $1 \mathrm{~h}$ after administration of CT (50, 100 and $200 \mathrm{mg} / \mathrm{kg}$, i.p.) or dexamethasone (DEXA, $2 \mathrm{mg} / \mathrm{kg}$, s.c.) using the technique previously described by Bastos et al. (2007) with modifications. The animals were euthanized by cervical dislocation $4 \mathrm{~h}$ after carrageenan injection. Shortly after, phosphate buffered saline (PBS) containing EDTA (1 mM, i.p., $10 \mathrm{~mL}$ ) was injected in the peritoneal cavity. Immediately, a brief massage was done for further fluid collection, which was centrifuged $(2000 \times \mathrm{g}$ for 5 min) at room temperature. The supernatant was disposed and PBS (1 mL) was added to the precipitate. An aliquot of the precipitate suspension $(10 \mu \mathrm{L})$ was dissolved in Turk solution (200 $\mu \mathrm{L}$ ) for counting of the total cells in a Neubauer chamber under optic microscopy. The results were expressed as the number of leukocytes $/ \mathrm{mL}$. The percentage of the leukocyte inhibition was calculated as $(1-T / C) \times 100$, where $T$ represents leukocyte counts for the treated groups and $C$ represents leukocyte counts for the control (vehicle).

\subsection{Carrageenan- and arachidonic acid-induced hind paw edema in rats}

Paw edema was induced by an intraplantar administration of $0.1 \%$ carrageenan in normal saline solution (Winter et al., 1962) or $0.5 \%$ arachidonic acid in $0.2 \mathrm{M}$ carbonate buffer, $\mathrm{pH}$ 8.2 (DiMartino et al., 1987) into the right hind paw of rats at a volume of 0.05 or $0.1 \mathrm{~mL}$, respectively. The edema volume was determined using a plethysmometer (Model LE 7500 Panlab, Barcelona, Spain) (Winter et al., 1962) prior to and $3 \mathrm{~h}$ after carrageenan injection or $1 \mathrm{~h}$ after arachidonic acid injection. CT (50, 100 and $200 \mathrm{mg} / \mathrm{kg}$, i.p.), control group (vehicle, 1 drop of Tween $800.2 \%$ in distilled water, the solvent for CT), and indomethacin (INDO, $10 \mathrm{mg} / \mathrm{kg}$, i.p.) or nordihydroguaiaretic acid (NDGA, $100 \mathrm{mg} / \mathrm{kg}$, i.p.) as reference drugs, were administered $1 \mathrm{~h}$ before injection of the phlogistic agents.
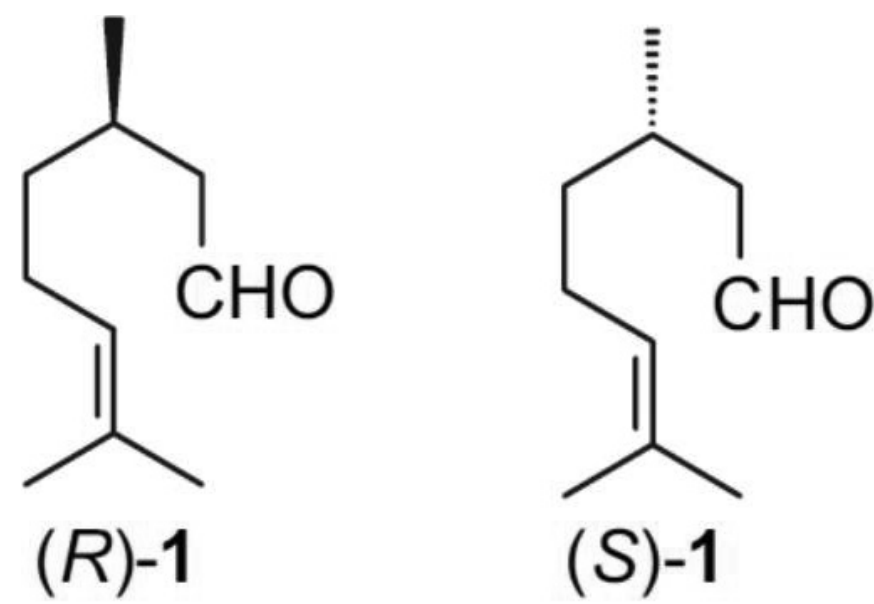

Figure 1. The enantiomers of citronellal (racemic mixture - $R$ and $S$ enantiomers)

\subsection{Redox-protective activity}

One hour after administration of CT (200 mg/ $\mathrm{kg}$, i.p.) or saline, rats were anesthetized with thiopental sodium $(45 \mathrm{mg} / \mathrm{kg}$, i.p.). Blood was collected by cardiac puncture using heparinized syringes and immediately centrifuged $(800 \times \mathrm{g}, 15 \mathrm{~min})$ at room temperature in presence of $2.5 \mathrm{mM}$ butylated hydroxitoluene (BHT). The supernatant was quickly collected and placed on ice for determination of thiobarbituric acid (TBA) reactive substances (TBARS) and residual carbonyl derivatives (RCD) using Lapena et al. (2001) and Resnick \& Packer (1994) modified methods, respectively. At the same time, liver of rats was removed, washed three times with $1.15 \%$ potassium chloride $(\mathrm{KCl})$ solution, dried, weighed, homogenized in $1.15 \% \mathrm{KCl}$ and centrifuged $(3000 \times \mathrm{g}$ for $10 \mathrm{~min})$ at room temperature in presence of $2.5 \mathrm{mM}$ BHT. The supernatant was quickly collected and placed on ice for posterior analysis of TBARs and RCD.

\subsection{Determination of TBARs}

Aliquots of blood or liver samples $(500 \mu \mathrm{L})$ were added to a reaction mixture $(1 \mathrm{~mL})$ containing equal amounts of $15 \%$ trichloroacetic acid (TCA), $0.25 \mathrm{~N} \mathrm{HCl}, 0.375 \%$ TBA, $2.5 \mathrm{mM}$ BHT and $8.1 \%$ sodium dodecyl sulphate (SDS, $100 \mu \mathrm{L}$ ). The $\mathrm{pH}$ of the reaction mixture was adjusted to 0.9 with $\mathrm{HCl}$ and then it was heated at $95{ }^{\circ} \mathrm{C}$ for $30 \mathrm{~min}$ in an oven. BHT was used to prevent lipid peroxidation during heating. After cooling the mixture to room temperature and adding $4 \mathrm{~mL}$ of $n$-butanol, reaction mixtures were centrifuged $(800 \times \mathrm{g}$ for $15 \mathrm{~min}$ ) at room temperature in presence of $2.5 \mathrm{mM}$ BHT. The supernatant was collected and its absorbance was measured at $532 \mathrm{~nm}$. The molar extinction coefficient used to quantify malondialdehyde was $1.54 \times 10^{-5} \mathrm{M}^{-1} \mathrm{~cm}^{-1}$. Results as equivalents of malondialdehyde (MDA) were expressed in nmol.mL $\mathrm{m}^{-1}$ plasma or nmol.g-1 tissue.

\subsection{Determination of $R C D$}

Aliquots of blood or liver samples $(200 \mu \mathrm{L})$ were mixed with dinitrophenylhydrazine (DNPH, $800 \mu \mathrm{L}$ ), incubated at \pm 37 ${ }^{\circ} \mathrm{C}$ for one hour in the dark. Mixtures were stired every 15 min during the incubation period. Then, $15 \%$ TCA $(1000 \mu \mathrm{L})$ was added to samples, which were centrifugated $(1000 \times \mathrm{g}$ for $10 \mathrm{~min}$ ) at room temperature in presence of $2.5 \mathrm{mM} \mathrm{BHT}$. The supernatant was then discarded and $15 \%$ TCA $(800 \mu \mathrm{L})$ was added again to the precipitate and the resulting mixture stired. After centrifugation $(1000 \times \mathrm{g}$ for $10 \mathrm{~min})$, the precipitate was washed three times with ethanol/ethyl acetate $(1: 1$, $800 \mu \mathrm{L})$ to remove the free DNPH and lipid contaminants. The final precipitate was resuspended in $6 \mathrm{M}$ guanidine $(400 \mu \mathrm{L})$ and incubated at $\pm 37{ }^{\circ} \mathrm{C}$ for $10 \mathrm{~min}$. The insoluble material was removed by additional centrifugation $(1000 \times \mathrm{g}$ for $5 \mathrm{~min}$ ) at room temperature, while the supernatant was collected. The molar extinction coefficient used to quantify spectrophotometrically the absorbance of the supernatant at $360 \mathrm{~nm}$ was $22,000 \mathrm{M}^{-1} \mathrm{~cm}^{-1}$. Results were expressed in nmol. $\mathrm{mL}^{-1}$ plasma or nmol.g ${ }^{-1}$ tissue.

\subsection{Statistical analysis}

The data obtained in the anti-inflammatory tests were evaluated by one-way analysis of variance (ANOVA) followed 
by Tukey's test. The data from the redox test were evaluated by Student's $t$ test. Differences were considered to be statistically significant when $\mathrm{p}<0.05$.

\section{RESULTS}

Carrageenan increased leukocyte migration to the peritoneal cavity in the experimental animals $4 \mathrm{~h}$ after stimulation, which was characterized by the increase in the leukocyte number in the fluid collected from the cavity. It was significantly $(\mathrm{p}<0.01)$ inhibited in $92.2 \%$ when mice were previously treated with the control drug dexamethasone ( $2 \mathrm{mg} / \mathrm{kg}$, s.c.), as can be seen in Fig. 2. When CT was administered to mice, its inhibitory effect on the migration of leukocytes was dose-dependent, with inhibitions of $14,46.1$ and $65.6 \%$ at 50, 100 and $200 \mathrm{mg} / \mathrm{kg}$ (i.p.), respectively. However, it prevented significantly $(\mathrm{p}<0.05$ and $\mathrm{p}<0.01$, respectively) the carrageenan-induced peritonitis only at 100 and $200 \mathrm{mg} / \mathrm{kg}$ (s.c.). INSERT FIGURE 2

To determine the possible anti-inflammatory effects of CT, carrageenan- and arachidonic acid-induced hind paw edema models in rats were used. When carrageenan was used as inductor of edema (Fig 3A), CT did not exhibit any significant $(\mathrm{p}>0.05)$ anti-inflammatory effect when administered at 50 $\mathrm{mg} / \mathrm{kg}$ (i.p.), although the edema volume in this concentration was reduced in 5.5\% when compared to the control (vehicle). However, at the highest tested concentrations, 100 and 200 $\mathrm{mg} / \mathrm{kg}$ (i.p.), CT inhibited significantly $(\mathrm{p}<0.05)$ the increase in the edema volume in 18.5 and $22.3 \%$, respectively. Control drug, INDO (10 mg/ kg, i.p.), showed the highest inhibition of edema volume (31\%). INSERT FIGURE 3

NDGA administration (10 $\mathrm{mg} / \mathrm{kg}$, i.p.) produced a significant $(p<0.01)$ and marked inhibition $(49.6 \%)$ of the paw edematous response induced by arachidonic acid injection, as can be seen in Fig. 3B. When the rats were treated with CT

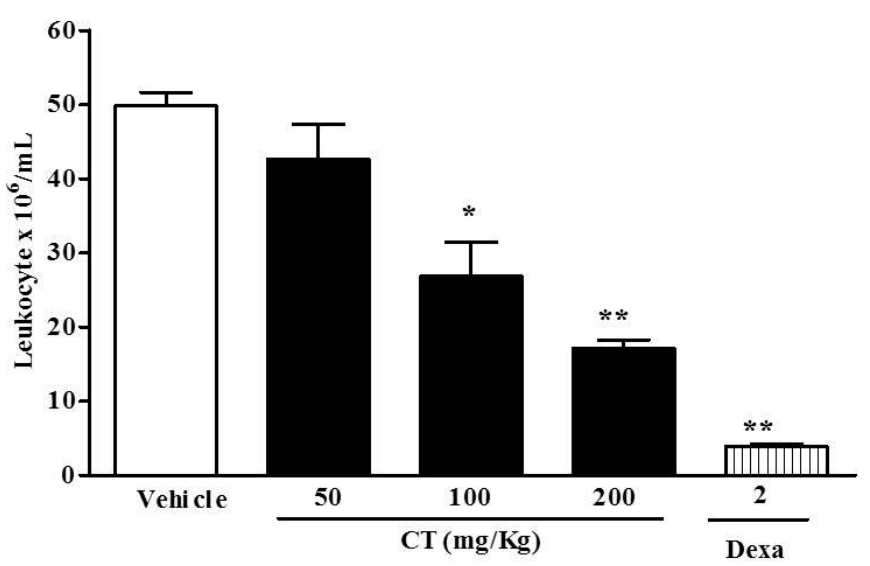

Figure 2. Effect of $\mathrm{CT}$ on leukocyte migration to the peritoneal cavity induced by carrageenan: Groups of rats were pre-treated with vehicle, dexamethasone (DEXA, $2 \mathrm{mg} / \mathrm{kg}$, s.c.) and CT (50, 100 and $200 \mathrm{mg} / \mathrm{kg}$, i.p.) $1 \mathrm{~h}$ before carrageenan administration $(500 \mu \mathrm{g} /$ cavity, i.p., $500 \mu \mathrm{L})$ to induce peritonitis. Cell counting was performed $4 \mathrm{~h}$ after the injection of carrageenan. Each value represents the mean \pm S.E.M. Asterisks denote statistical significance when means were compared to the vehicle group, where ${ }^{*} \mathrm{p}<0.05$ or ${ }^{* *} \mathrm{p}<0.01$ by ANOVA followed by Tukey's test. previously to the administration of the fatty acid, it exerted a significantly $(p<0.05)$ higher inhibitory effect on edema formation related to the induction caused by carrageenan because volume edema was reduced in 31, 34.1 and $38.8 \%$ at 50, 100 and $200 \mathrm{mg} / \mathrm{kg}$, respectively. INSERT FIGURE 4

When the redox-protective activity of CT was investigated, it was demonstrated CT could not minimize blood lipoperoxidation deleterious effects caused by reactive oxygen species (ROS) since the levels of TBARS represented by malondialdehyde were not significantly $(p>0.05)$ reduced when compared the control vehicle (Fig 4A). However, lipoperoxidation in the hepatic tissue of rats was effectively reduced in $75.8 \%$ when compared to vehicle, as is shown in Fig. $4 \mathrm{~B}$. On the other hand, the investigation of the protective effect of $\mathrm{CT}$ on protein oxidation by carbonylation, which is characterized by the levels of RCDs, showed this monoterpene can prevent structural modifications of proteins in plasma and liver. Fig 5 A shows a significant $(p<0.05)$ inhibition of protein
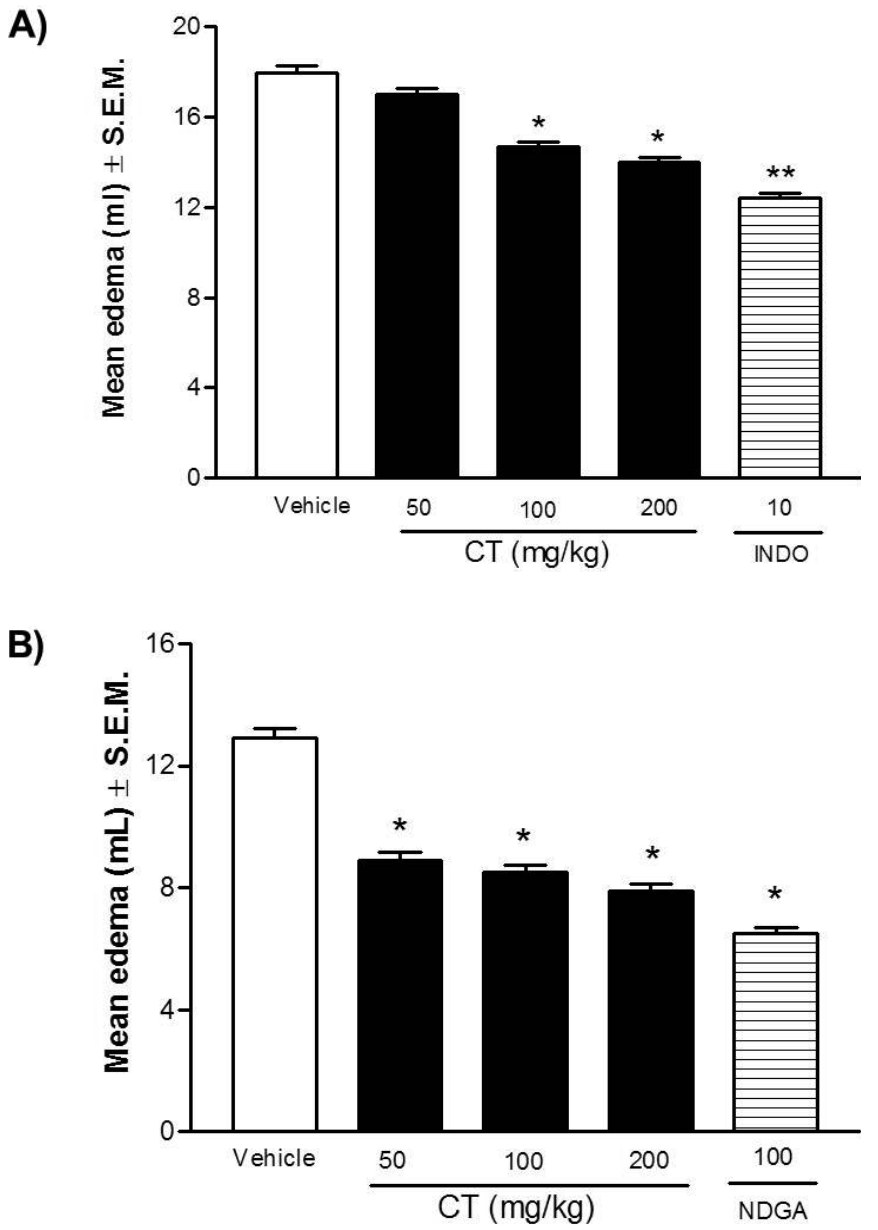

Figure 3. Effects of indomethacin (INDO, $10 \mathrm{mg} / \mathrm{kg}$, i.p.), nordihydroguaiaretic acid (NDGA, $100 \mathrm{mg} / \mathrm{kg}$, i.p.) and CT (50, 100 and $200 \mathrm{mg} / \mathrm{kg}$, i.p.) on $1 \%$ carrageenan- (A) and $0.5 \%$ arachidonic acid- (B) induced hind paw edema in rats. Each value represents the mean of edema volume \pm S.E.M. Asterisks denote statistical significance when means were compared to the respective vehicle groups, where ${ }^{*} p<0.05$ and ${ }^{* *} p<0.01$ by ANOVA followed by Tukey's test. 
oxidation in $28.1 \%$ in plasmatic samples, while a reduction of $34.5 \%$, also significant ( $\mathrm{p}<0.01$ ), was observed for liver tissues. INSERT FIGURE 5

\section{DISCUSSION}

Many studies have shown monoterpenes have pharmacological activities such as antinociceptive, anti-inflammatory and antioxidant (Almeida et al., 2001; De Sousa et al., 2006; De Sousa et al., 2007; Quintans-Júnior et al., 2010). Therefore, the aim of this study was to evaluate the anti-inflammatory and antioxidant effects of citronellal (CT) using in vivo and in vitro tests.

The inflammation induced by carrageenan involves cell migration and plasma exudation mediated by the production of inflammatory mediators such as histamine, serotonin, bradykinin, nitric oxide, interleukin (IL)-1 $\beta$ and IL-6, tumor necrosis factor (TNF)- $\alpha$, and prostaglandins, which were previously shown to recruit leukocytes, such as neutrophils, in several experimental models (Salvemini et al., 1996; Loram et al., 2007). In addition, it is known the production of prostaglandin $\mathrm{E}_{2}$, which is involved in cell migration and development of paw

A)

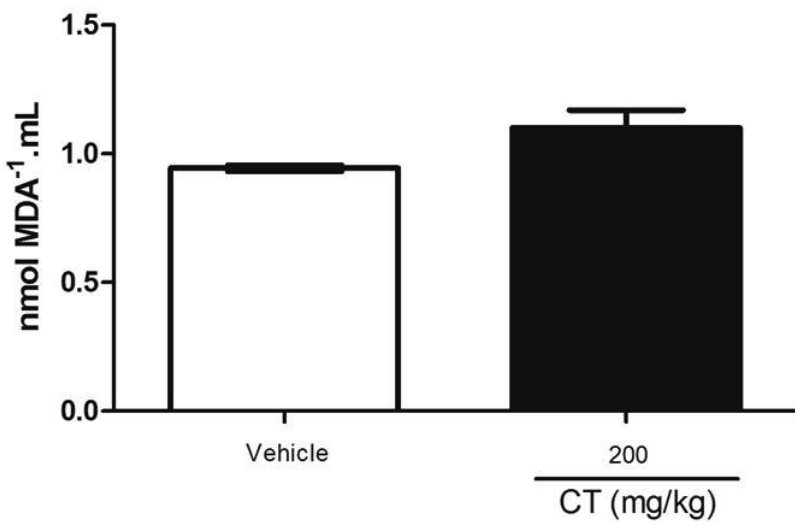

B)

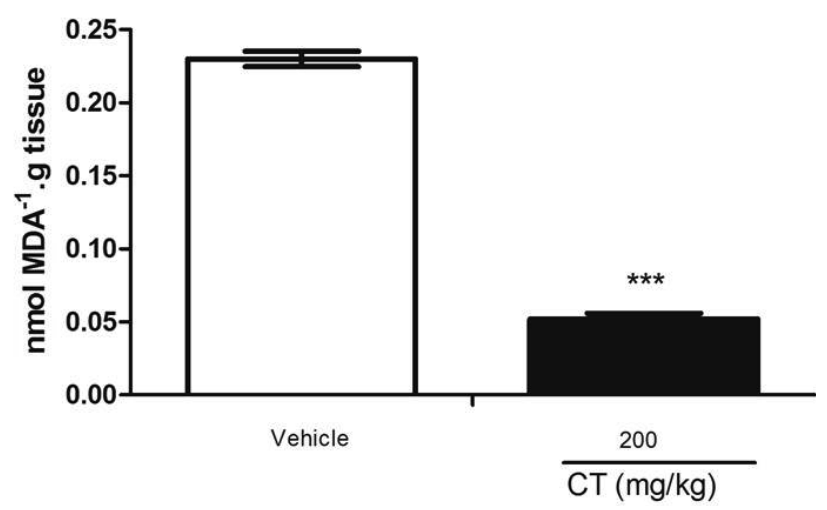

Figure 4. Redox-protective effect of $\mathrm{CT}(200 \mathrm{mg} / \mathrm{kg}$, ip.) on MDA levels in plasma (A) and liver (B) of rats. Each value represents the mean \pm S.E.M. Asterisks denote statistical significance when means were compared to the respective vehicle groups, where ${ }^{* * *} \mathrm{p}<0.001$ by upaired Student's $t$ test $(\mathrm{n}=8)$. edema, increases $3 \mathrm{~h}$ after carrageenan administration through cyclooxygenase-2 (COX-2) activation (Ribeiro et al., 2010). Therefore, the compound is extensively used in studies assessing the anti-inflammatory effect of steroidal and non-steroidal drugs (Vinegar et al., 1987). In the peritonitis model, CT acted similarly to DEXA, an immunosuppressant drug, by inhibiting leukocyte migration induced by i.p. injection of carrageenan in a dosedependent manner. CT also reduced the paw edema volume at 100 and $200 \mathrm{mg} / \mathrm{kg}$ similarly to INDO, an inflammatory drug well-known for affecting cyclooxygenase (COX) 1 and 2, the enzymes participating in the prostaglandin biosynthesis from arachidonic acid (DiMartino et al., 1987). Although a mechanism for this inhibition was not an aim in the present study, it can be suggested CT action on reducing cell migration and paw edema is associated with the inhibition of the biosynthesis of the inflammatory mediators previously mentioned.

Arachidonic acid-induced paw edema in rat is also a widely used method for evaluating the anti-inflammatory activity of lipoxygenase inhibitors and other agents with a mechanism of action different from cyclooxygenase inhibitors. The lipoxygenase pathway uses arachidonic acid and 5-lipoxygenase to produce leukotrienes (LTs) such as LTC4 and LTD4, which are involved in inflammatory reactions as proinflammatory mediators and cause edema with increased microvascular permeability. Thus, owing to

A)

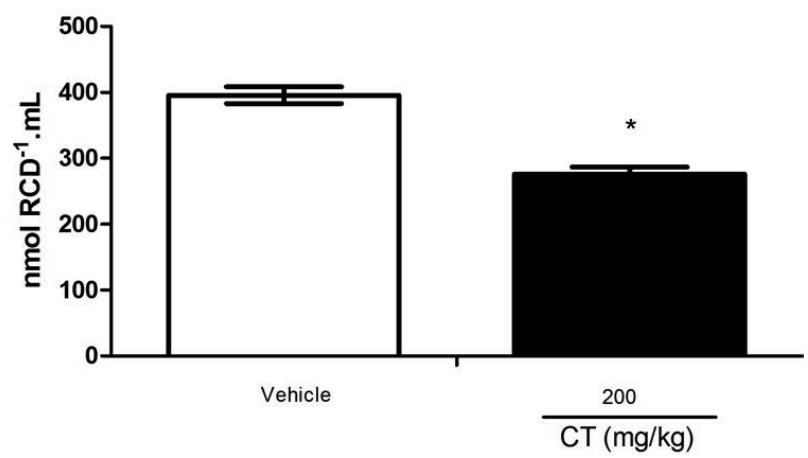

B)

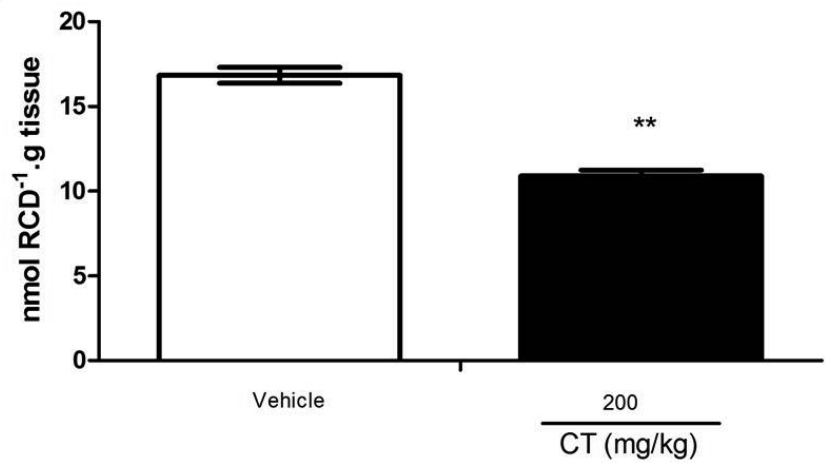

Figure 5. Redox-protective effect of CT (200 mg / kg, ip.) on RCD levels in plasma (A) and liver (B) of rats. Each value represents the mean \pm S.E.M. Asterisks denote statistical significance when means were compared to the respective vehicle groups, where ${ }^{*} p$ $<0.05$ and ${ }^{* *} \mathrm{p}<0.01$ by unpaired Student's $t$ test. 
the contribution of leukotrienes to the pathogenesis of many inflammatory processes, they also represent an important target for therapeutic regulation. The paw edema induced by arachidonic acid is perceptibly reduced by lipoxygenase inhibitors and dual inhibitors of arachidonic acid metabolism such as phenidone and corticosteroids (DiMartino et al., 1987). In the present study, CT inhibited the formation of edema by reducing its final volume in $30-40 \%$ similarly to NDGA. Contrary to INDO, which does not act on the lipooxygenase pathway of the arachidonic acid, NDGA is able to inhibit this enzyme and was used in the present study as the control drug (DiMartino et al., 1987; Trang et al., 2004). Thus, although lipoxygenase by-products were not measured, this finding suggests CT may be acting as an inhibitor of the enzyme lipoxygenase in the arachidonic acid metabolism. Further studies can establish if CT acts as a lipoxygenase only inhibitor or if it has a dual inhibitor role, inhibiting also the cyclooxygenases.

There is a consensus that during the inflammatory process, leukocytes cells such as eosinophils, basophils, neutrophils and monocytes are activated and interact with resident cells stimulating inflammatory and immunological mediators, whose metabolism can lead to the production of reactive oxygen species (ROS) (Barnes, 2008). ROS can activate nuclear factors of transcription and activator protein-1 (AP-1) and amplify the inflammatory response (Sugiura and Ichinose, 2008). Thus, CT effect on ROS production was investigated in a group of untreated rats by measuring the thiobarbituric acid-reactive substances (TBARS) such as malondialdehyde, a by-product of lipid peroxidation, and protein carbonyl group oxidation (Resnick \& Packer, 1994; Lapenna et al., 2001). Although the study was performed in basal conditions, this primary investigation showed CT can reduce oxidation of lipids in liver and protein oxidation in liver and plasma of rats, which is an indicative of its potential as an anti-ROS agent. Further studies on the mechanisms by which CT is exerting its antiinflammatory activity can establish CT potential against ROS in inflammatory conditions. It is known that many antioxidants are first metabolized in the liver before their release in the blood stream (Vaziri et al., 2000). Therefore, this organ has a higher content of antioxidants, which will minimize ROS faster and in a more efficient way than in other organs. This may explain why lipids and proteins in liver were better protected in the present study.

According to Chiaradia et al. (2009), the evaluation of the chemical composition and in vitro antioxidant potential of the essential oil of citronella (C. winterianus) showed that CT is one of the major compounds $(35.28 \%)$. Furthermore, the antioxidant potential of the oil is higher than observed for the essential oil of other vegetable species, which was believed to be directly proportional to the higher CT concentration. The mechanism whereby CT protects the cellular lipid and protein structures from oxidative action of ROS occurs through abstraction of one hydrogen atom or addiction of radical $\mathrm{OH}$ to the double carbon-carbon bond of $\mathrm{CT}$ (Harrison et al., 2007), thus preventing lipoperoxidation and protein oxidation (Lertsatitthanakorn et al., 2006). The results of the present study support the hypothesis that CT possesses antiinflammatory and redox protective activities. Therefore, CT is of potential benefit to manage inflammatory disorders and correlated damages caused by oxidant agents.

\section{ACKNOWLEDGEMENTS}

We want to thank Mr. Osvaldo A. Santos for the technical support during the present study. We are grateful to the National Council of Technological and Scientific Development (Conselho Nacional de Desenvolvimento Científico e Tecnológico/CNPq/Brazil) [grant number 470290/2008$0]$ and the Research Supporting Foundation of the State of Sergipe (Fundação de Apoio à Pesquisa e à Inovação Tecnológica do Estado de Sergipe/FAPITEC-SE) [grant number 019.203.00860/2009-6] for the financial support.

\section{REFERENCES}

ALMEIDA RN, NAVARRO DS, BARBOSA-FILHO JM (2001) Plants with central analgesic activity. Phytomed 8: 310-322.

BARNES PJ (2008) Immunology of asthma and chronic obstructive pulmonary disease. Nat Rev Immunol 8: 183-92.

BASTOS LF, MERLO LA, ROCHA LT, COELHO MM (2007) Characterization of the antinociceptive and anti-inflammatory activities of doxycycline and minocycline in different experimental models. Eur J Pharmacol. 576: 171-179.

CHIARADIA V, GRZEGOZESKI LP, CANSIAN RL, EMMERICH DJ, PAROUL N (2009) Composição Química e Atividade Antioxidante da Citronela (Cymbopogon winterianus). Resumo XVII Encontro de Química da Região Sul. http://www.sbqsul.furg.br/ocs/index.

DE SOUSA DP, GONÇALVES JCR, QUINTANS-JÚNIOR LJ, CRUZ JS, ARAÚJO DAM, ALMEIDA RN (2006) Study of anticonvulsant effect of citronellol, a monoterpene alcohol, in rodents. Neurosci Lett 401: 231-235.

DE SOUSA DP, JÚNIOR EVM, OLIVEIRA FS, ALMEIDA RN, NUNES XP, BARBOSA-FILHO JM (2007) Antinociceptive activity of strutural analogues of Rotundifolone: Structure-activity relationship. Z. Naturforsh 62c: 39-42.

DIMARTINO MJ, CAMPBELL JR GK, WOLFF CE, HANNA N (1987) The pharmacology of arachidonic acid-induced rat paw edema. Agents and Actions 21 (3-4): 303-305.

GHERLARDINI C, GALEOTTI N, MAZZANTI G (2001) Local anaesthetic activity of monoterpenes and phenylpropanes of essential oils. Planta Med 67: 564-566.

GUIMARÃES AG, OLIVEIRA GF, MELO MS, CAVALCANTI SCH, ANTONIOLLI AR, BONJARDIM LR, SILVA FA, SANTOS JPA, ROCHA RF, MOREIRA JCF, ARAÚJO AAS, GELAIN DP, QUINTANS-JÚNIOR LJ (2010) Bioassay-guided evaluation of antioxidant and antinociceptive activities of carvacrol. Basic Clin Pharmacol Toxicol 107: 949-957.

HARRISON JC, HAM JE, WELLS JR (2007) Citronellal reactions with ozone and $\mathrm{OH}$ radical: Rate constants and gas-phase products detected using PFBHA derivatization. Atmospheric Environment 41: 4482-4491.

LAPENNA D, CIOFANI G, PIERDOMENICO SD, GIAMBERARDINO MA, CUCCURULLO F (2001) Reaction conditions affecting the relationship between thiobarbituric acid reactivity and lipid peroxides in human plasma. Free Radical Biology \& Medicine 31: 331-335.

LENARDÃO EJ, BOTTESELLE GV, AZAMBUJA F, PERIN G, JACOB RG (2007) Citronellal as key compound in organic synthesis. Tetrahedron 63: 6671-6712.

LERTSATITTHANAKORN P, TAWEECHAISUPAPONG S, AROMDEE C, KHUNKITTI W (2006) In vitro bioactivities of essential oils used for acne control. The International Journal of Aromatherapy 16: 43-49.

LORAM LC, FULLER A, FICK LG, CARTMELL T, POOLE S, MITCHELL D (2007) Cytokine profiles during carrageenan-induced inflammatory hyperalgesia in rat muscle and hind paw. J Pain 8: 127-136.

MELO MS, SENA LCS, BARRETO FJN, BONJARDIM LR, ALMEIDA JRGS, LIMA JT, DE SOUSA DP, QUINTANS-JÚNIOR LJ (2010) Antinociceptive effect of citronellal in mice. Pharm Biology 48: 411-416.

MENEZES IAC, MOREIRA IJA, PAULA JWA, BLANK AF, ANTONIOLLI AR, QUINTANS-JÚNIOR LJ, SANTOS MRV (2010) Cardiovascular effects induced by Cymbopogon winterianus essential oil in rats: involvement of calcium channels and vagal pathway. J Pharm Pharmacol 62: 215-2-22.

QUINTANS-JÚNIOR LJ, SOUZA TT, LEITE BS, LESSA NMN, BONJARDIM LR, SANTOS MRV, ALVES PB, BLANK AF, ANTONIOLLI AR (2008) Phythochemical screening and anticonvulsant activity of Cymbopogon winterianus Jowitt (Poaceae) leaf essential oil in rodents. Phytomed 15: 619-624. 
OUINTANS-JÚNIOR LJ, MELO MS, DE SOUSA DP, ARAÚJO AAS, ONOFRE ACS, GELAIN DP, GONÇALVES JCR, ARAÚJO DAM, ALMEIDA JRGS, BONJARDIM LR (2010) Antinociceptive activity of citronellal in formalin-, capsaicin- and glutamate-induced orofacial pain in rodents and its action on nerve excitability. J Orofacial Pain 24: 305-312.

RESNICK AZ, PACKER K (1994) Oxidative damage to proteins: spectrophotometric method for carbonyl assay. Methods Enzymol 233: 263-357.

RIBEIRO RV, SILVA RM, LIMA JCS, MARTINS DTO (2010) Antiinflammatory, antinociceptive and antipyretic effects of hydroethanolic extract from Macrosiphonia velame (A. St.-Hil.) M. Arg. in animal models. Braz L Pharma Sci 46: 515-523.

SALVEMINI D, WANG ZQ, WYATT PS, BOURDON DM, MARINO MH, MANNING PT, CURRIE MG (1996) Nitric oxide: A key mediator in the early and late phase of carrageenan-induced rat paw inflammation. $\mathrm{Br}$ Pharmacol 118: 829-838.
SUGIURA H, ICHINOSE M (2008) Oxidative and nitrative stress in bronchial asthma. Antioxid Redox Signal 10: 785-797.

TRANG T, MCNAULL B, QUIRION R, JHAMANDAS K (2004) Involvement of spinal lipoxygenase metabolites in hyperalgesia and opioid tolerance. Eur J Pharmacol 491: 21-30.

VAZIRI ND, WANG XQ, OVEISI F, RAD B (2000) Induction of oxidative stress by glutathione depletion causes severe hypertension in normal rats. Hypertension 36:142-146.

VINEGAR R, TRUAX JF, SELPH JL, JOHNSTON PR, VENABLE AL, MCKENZIE KK (1987) Pathway to carrageenan-induced inflammation in the hind limb of the rat. Fed Proceed 46: 118-126.

WINTER CA, RISELEY EA, NUSS GW (1962) Carrageenan-induced edema in the hind paw of the rats as an assay for anti-inflammatory drugs. Proc Soc Exp Biol Med 111: 544-547. 